\title{
Prevalence of Exercise-Induced Bronchospasm by laboratory exercise challenge among Ragunan Sport School athletes
}

\author{
Ignatio Rika ${ }^{1}$, Imam Budiman ${ }^{2}$, Jull Kurniarobbi ${ }^{3}$, Noviar Mahmud ${ }^{4}$
}

\begin{abstract}
Abstrak
Exercise-induced bronchospasm (EIB) sering dijumpai pada atlet remaja. Penelitian untuk mengetahui prevalensi EIB pada atlet remaja di Indonesia belum pernah dilakukan. Penelitian ini dilakukan untuk mengetahui prevalensi EIB pada atlet Sekolah Olahraga Ragunan dengan menggunakan tes latihan di laboratorium. Setiap atlet melakukan latihan sepeda statis (Monark, Swedia) hingga mencapai intensitas latihan minimal pada 90\% laju jantung maksimal. "Force expiratory ventilation" (FEV) diperiksa dengan menggunakan spirometri (Minato AS-PAL, Jepang) pada menit ke 0, 5, 10 dan 20 pasca latihan. Diagnosis EIB ditentukan bila terdapat penurunan $\mathrm{FEV}_{1} 10 \%$ atau lebih dibanding nilai basal. Suhu dan kelembaban ruangan selama penelitian berkisar $28^{\circ} \mathrm{C}$ $31{ }^{\circ} \mathrm{C}$ dan $74 \%-82 \%$. Sebanyak 168 atlet mengikuti penelitian ini. Terdapat 23 atlet yang terbukti positif EIB. Persentase penderita EIB terbanyak adalah di cabang taekwondo (54,5\%). Jumlah atlet yang terbukti EIB yang berasal dari cabang yang kurang asmogenik sebanyak 16 orang (70\%). Terdapat 17 atlet wanita (17,5\%) dan 6 atlet laki-laki (8,4\%) yang menderita EIB. Ternyata, prevalensi EIB pada atlet remaja cukup besar, dan terjadi lebih banyak pada atlet wanita. Selain itu, tes latihan yang dilakukan di laboratorium dapat mendiagnosis EIB pada atlet dari cabang olahraga yang kurang mencetuskan EIB. (Med J Indones 2008; 17: 33-6)
\end{abstract}

\begin{abstract}
Exercise-induced bronchospasm (EIB) is a common condition among adolescent athletes. There has been no study examining the prevalence of EIB among adolescent athletes in Indonesia. This study aimed to get the prevalence of EIB among Ragunan Sport School athletes by laboratory exercise challenge. Subjects performed static cycle ergometer exercise (Monark, Sweden) to reach minimal workload of $90 \%$ maximal heart rate. Force expiratory ventilation $\left(F E V_{l}\right)$ was examined by spirometry (Minato AS-PAL, Japan) at minute 0, 5, 10 and 20 post exercise. The EIB was defined as a decline of FEV $V_{1}$ as much as $10 \%$ or more from baseline value. Room temperature and humidity were $28^{\circ} \mathrm{C}-31^{\circ} \mathrm{C}$ and $74 \%-82 \%$ respectively. There were 168 athletes from 12 sport types who participated in this study. Among them, 23 athletes (13.7\%) were EIB positive. The highest percentage of EIB was in taekwondo (54.5\%). Sixteen athletes with EIB (70\%) were from less asthmogenic sports. Athletes with EIB consisted of 17 (17.5\%) females and 6 $(8.4 \%)$ males. In conclusion, the prevalence of EIB among adolescent athletes was moderately high, and was more prevalent in female. More over, laboratory exercise challenge could elicit EIB in less asthmogenic sport. (Med J Indones 2008; 17: 33-6)
\end{abstract}

Keywords: adolescent athlete, asthmogenic sports

Exercise-induced bronchospasm (EIB) is a clinical syndrome characterized by transient airflow obstruction associated with strenuous activities. ${ }^{1}$ Bronchospasm typically peaks $8-15$ after cessation of physical exercise and resolves within 60 minutes later. ${ }^{1}$ It is more frequent in athletes, ${ }^{2,3}$ and affects $10-50 \%$ elite athletes and $12 \%$ high school athletes. ${ }^{3}$ Prevalence of EIB

\footnotetext{
${ }^{1}$ Department of Physiology, Faculty of Medicine, Atmajaya University, Jakarta, Indonesia

${ }^{2}$ Department of Pediatrics, Faculty of Medicine, University of Indonesia, Jakarta, Indonesia

3 Department of Sport Medicine, Faculty of Medicine, University of Indonesia, Jakarta, Indonesia

${ }^{4}$ Indonesian Association of Sport Medicine Doctor, Jakarta, Indonesia
}

depending on the sport in which they are involved and environmental condition. High intensity sports are usually asthmogenic. Some sports are included as high asthmogenic sports such as long distance running, basketball, soccer, cycling, etc. ${ }^{3}$ Environment is another important factor in determining the prevalence of EIB. Higher prevalence of EIB is found in winter athletes such as ice skater. ${ }^{4}$ Hyperventilation, low temperature and humidity cause airway cooling and drying, the conditions that have been proposed as the mechanism in the aetiology of EIB. ${ }^{5}$

EIB is often asymptomatic. ${ }^{1,5}$ Diagnosing EIB based on their symptoms and history of hipersensitivity is less effective. ${ }^{6,7}$ It has only moderate sensitivity and specificity, leading to both an overdiagnosis or under- 
diagnosis. ${ }^{7}$ A study by Rundell et al cited by Holzer \& Zbrukner found that only $61 \%$ of EIB positive athletes reported symptoms while, $45 \%$ of those negative also reported symptoms. ${ }^{7}$ Therefore, it is suggested to use a method that has a higher sensitivity and specificity to detect EIB. Exercise challenge is one of the methods that is used widely to diagnose EIB in some studies.

It is important to diagnose EIB in athletes, because asthmatic athletes will have lower aerobic and anaerobic capacity which in turn can prevent the affected athletes to achieve the best performance. ${ }^{8}$ By recognizing EIB, we can make a plan to treat and to train athletes well. Being treated properly, athletes with EIB can reach their best performance as in 1984 US Olympic team, in which $61 \%$ of athletes with EIB won medals. ${ }^{2}$

The prevalence of EIB among athletes in Indonesia hasn't been known yet. Therefore, this is study aimed to examine prevalence of EIB among adolescent athletes in Indonesia.

\section{METHODS}

This was a crosss sectional study. Primary data were taken at Ragunan Sport School Jakarta from July through August 2004. Subjects were all students of the Ragunan Sport School. Each athletes completed a questionnaire consisted of 10 questions related to personal data and exclusion criterias. Subjects were excluded if they were taking medication influencing heart and bronchus activity and having diseases limiting the outcome measures. Written information and procedures were outlined and written informed consent was obtained from athletes and coaches. All procedures were conducted in Ragunan Sport Clinic. All procedures were approved by Ethical Committee for Medical Research, Faculty of Medicine of the University of Indonesia.

Physical examination was performed to measure height, weight, resting heart rate and baseline spirometry. Height was measured using stadiometer, weight was measured using body weight scale (Soehnle, Germany). Resting heart rate was recorded by Polar heart rate recorder (Vantage $\mathrm{NV}^{\mathrm{TM}}$, Polar Electro Oy, Finland) after resting in supine for 5 minutes. Baseline spirometry using Minato AS-PAL (Japan) was conducted to measure baseline $\mathrm{FEV}_{1}$, prediction $\mathrm{FEV}_{1}$ and $\mathrm{FEV}_{1} / \mathrm{FVC}$.
Each athlete performed laboratory exercise challenge by exercising on static cycle ergometer (MonarkSweden) for 6 minutes at 100 pedals/minute. Athletes had to reach exercise intensity of $90 \%$ maximal heart rate (age-20) or more. Initial load was 1.0 kilo pound (kp) for girls and $1.5 \mathrm{kp}$ for boys. Load was increased $0.5 \mathrm{kp}$ per minute to reach the target heart rate. Exercise heart rate was recorded every minute. Spirometry test was performed at $0,5,10$, and 20 minutes after cessation of exercise challenge. A positive EIB was defined as a decrease in $\mathrm{FEV}_{1}$ of $10 \%$ or more.

Laboratory exercise challenge was performed at $14.30 \mathrm{pm}$ - $17.30 \mathrm{pm}$, in a clinical room without controlling room temperature and humidity. Room temperature and humidity ranges were $28^{\circ} \mathrm{C}-31^{\circ} \mathrm{C}$ and $74 \%-82 \%$ respectively.

Statistical analysis was performed using the software package of SPSS version 11.5. Unpaired t-test (for normal data distribution) or Mann-Whitney (for not normal data distribution) was used to analyse the differences of characteristics between gender. The level of statistical significance was set at a $P$ value less than 0.05 .

\section{RESULTS}

A total of 168 athletes from 12 sports type participated in this study. The subjects' age ranged from 11 to 18 years old. The subjects consisted of 71 males (42.3\%) and 97 females (57.7\%). Table 1 shows the characteristics of the subjects. Age, height and baseline $\mathrm{FEV}_{1}$ were different between males and females $(P=0.00)$. The males subjects had older age, taller height and higher value of baseline $\mathrm{FEV}_{1}$ than do females.

Table 1. Characteristics of the subjects

\begin{tabular}{lccccc}
\hline & Boys & $(\mathrm{n}=71)$ & Girls & $(\mathrm{n}=97)$ & $\begin{array}{c}P \\
\text { value }\end{array}$ \\
\cline { 2 - 5 } & Mean & SD & Mean & SD & \\
\hline Age (year) & 15.87 & 1.49 & 14.85 & 1.56 & $0.00^{*}$ \\
$\begin{array}{l}\text { Height }(\mathrm{cm}) \\
\text { Body Mass Index } \\
\left(\mathrm{kg} / \mathrm{m}^{2}\right)\end{array}$ & 165.84 & 10.25 & 158.74 & 8.63 & $0.00^{*}$ \\
$\begin{array}{c}\mathrm{FEV}_{1} \text { baseline } \\
(\text { liter })\end{array}$ & 3.05 & 2.37 & 20.11 & 2.98 & 0.68 \\
$\begin{array}{c}\mathrm{FEV}_{1} \text { prediction } \\
(\%)\end{array}$ & 92.68 & 14.86 & 89.20 & 16.16 & 0.14 \\
$\mathrm{FEV}_{1} / \mathrm{FVC}(\%)$ & 98.56 & 3.12 & 98.77 & 3.15 & 0.58 \\
\hline
\end{tabular}

* Significantly different at $P<.05$ 
Table 2 shows prevalence of EIB. The prevalence of EIB was $13.7 \%$. Among all sports, taekwondo had the highest prevalence of EIB (54.5\%). There was no EIB found in archery, basketball and soccer athletes. The rate of EIB among female athletes was higher than among male athletes $(17.5 \%$ vs $8.5 \%)$. Chi-square test did not show significant difference of the prevalence between males and females.

Table 2. Prevalence of exercise-induced bronchoconstriction (EIB) among all sport

\begin{tabular}{lccc}
\hline & Incidence & of EIB [n (\%)] & $\begin{array}{c}\text { Team } \\
(\mathrm{n}=168)\end{array}$ \\
\cline { 2 - 3 } & Boys $(\mathrm{n}=71)$ & Girls $(\mathrm{n}=97)$ & \\
Less asthmogenic & & & \\
sports & & & \\
Archery & 0 & 0 & 0 \\
Athletics & $1(12.5 \%)$ & $2(16 \%)$ & $3(15 \%)$ \\
Gymnastic & $1(14 \%)$ & $1(7.7 \%)$ & $2(10 \%)$ \\
Lawn tennis & $1(20 \%)$ & $1(33 \%)$ & $2(25 \%)$ \\
Swimming & 0 & $1(16 \%)$ & $1(7 \%)$ \\
Table tennis & $1(14 \%)$ & 0 & $1(7 \%)$ \\
Taekwondo & $1(25 \%)$ & $5(71 \%)$ & $6(54.5 \%)$ \\
Volley-ball & $a$ & $4(21 \%)$ & $4(21 \%)$ \\
Weight-lifting & $1(25 \%)$ & $1(25 \%)$ & $2(25 \%)$ \\
Asthmogenic sports & & & \\
Badminton & $a$ & $2(13.3 \%)$ & $2(13.3 \%)$ \\
Basketball & 0 & 0 & 0 \\
Soccer & 0 & $b$ & 0 \\
\hline \multicolumn{1}{c}{ Total } & $6(8.45 \%)$ & $17(17.5 \%)$ & $23(13.7 \%)$ \\
\hline
\end{tabular}

${ }^{a}$ Consisted of female only.

${ }^{b}$ Consisted of male only.

Percentage of each gender is based on the number of subjects in each gender in certain sports. Percentage of team is based on the number of subjects in certain sports.

Table 3 shows the distribution of EIB according to the severity. There were eight subjects with severe EIB (35\%), which all came from less asthmogenic sports. Among athletes from asthmogenic sports, two athletes $(8.7 \%)$ had EIB and no athletes had severe EIB.

Tabel 3. Distribution of the EIB according the severity

\begin{tabular}{lccc}
\hline & $\begin{array}{c}\text { Mild EIB } \\
(\mathrm{n})\end{array}$ & $\begin{array}{c}\text { Severe EIB } \\
(\mathrm{n})\end{array}$ & $\begin{array}{c}\text { Total } \\
(\mathrm{n})\end{array}$ \\
\hline Less asthmogenic sports & 13 & 8 & 21 \\
Asthmogenic sports & 2 & - & 2 \\
\hline Total & 15 & 8 & 23 \\
\hline
\end{tabular}

\section{DISCUSSION}

This study has some limitations. There were twelve sports that consisted of a small number of athletes in each sport. Therefore, the number of atletes with EIB in each sport type did not reflect a real prevalence of that sport.

The purpose of this study was to examine the prevalence of EIB among adolescent athletes in Ragunan Sport School. To our knowledge, our study was the first study to examine the prevalence of EIB in Indonesia. We found that the prevalence of EIB in adolescent athletes was $13.7 \%$. This result was not so different from Rupp's study which found a prevalence of $12 \%$ in middle and high school athletes. ${ }^{9}$ However, our result is rather high compared to the result of Halstrand's study $(9.4 \%){ }^{6}$ These different results might be due to the exercise intensity challenge. Halstrand used field exercise challenge by running as fast as possible for 7 minutes, where it was difficult to control the workload. In field exercise, the subjects tend to slow their pace whenever they feel hard. In our study, we controled the workload and monitored the subject's heart rate. By controlling the load and monitoring the heart rate we could assure that the subjects could reach the intensity needed to yield hiperventilation and trigger EIB.

This study found that EIB was more prevalent in females than in males. The number of positive EIB in female was three times and the percentage was double of those among male, though the difference was not statistically significant. This finding was similar with Wilber's study. ${ }^{4}$ Some studies have raised several hypotheses about the different susceptibility to asthma between male and female. Hormonal factor and lung size have been suggested as the most likely factors that are able to influence the risk of asthma. ${ }^{10,11} \mathrm{We}$ did not evaluate hormonal status of our subjects but we were sure that most of them were at pubertal age. Another possible explanation is airway hyperresponsiveness. ${ }^{11}$ The airway hyperresponsiveness is related to the airway caliber. A smaller airway is more responsive than a bigger one. At puberty, females has smaller airway than do males so that females are more responsive and more susceptible to asthma. ${ }^{11}$ In our study, female subjects had smaller airway that was indicated by lower value of baseline $\mathrm{FEV}_{1}$. This could explain the higher prevalence of EIB among female athletes in this study.

There were twelve sports that were evaluated in this study. The highest percentage of EIB was in taekwondo athletes. The result of this study showed that the less asthmogenic sports (taekwondo, weight-lifting and 
volley ball) had more athletes with EIB than the asthmogenic sports (soccer and basketball). A previous study showed that 16 athletes (70\%) with EIB were from less asthmogenic sports. The degree of asthmogenic level of a sport is determined by the intensity of the sport. ${ }^{1,2}$ Taekwondo, weight-lifting and volley-ball are supposed to be low in intensity. ${ }^{2}$ Doing these sports will increase less oxygen demand and therefore will increase less ventilation. This will not be sufficient to cause airway cooling and airway drying and to provoke EIB. To provoke EIB in athletes of the less asthmogenic sports we need to give an exercise challenge with workload sufficient to produce at least $80 \%$ of maximal oxygen capacity or $90 \%$ of maximal heart rate. ${ }^{1}$ Based on the theory of intensity, we chosed to apply a laboratory exercise challenge instead of a sport-specific challenge. The intensity of exercise challenge of our study seemed to be able to diagnose unrecognized EIB in less asthmogenic sports.

Recent study also found that eight athletes (35\%) had fall of $\mathrm{FEV}_{1}$ more than $20 \%$ (Table 3). They were all from non-asthmogenic sports. This result was similar with Halstrand's study that found severe EIB in 33\% of subjects. ${ }^{6}$ The severity of EIB is determined by presence of airway infection, intensity of exercise, and environment condition. ${ }^{3}$ We did not evaluate the presence of airway infection. Environment condition of this study was not supportive to induce EIB (high temperature and humidity). Considering all athletes with severe EIB were from non-asthmogenic sports, the intensity of exercise was the most possible factor in triggering severe EIB in this study.

In conclusion, in this study, EIB was a common condition among adolescent athletes, and that a laboratory exercise challenge was able to elicit EIB in less asthmogenic sports. Moreover, EIB was more prevalent in females and in athletes of less asthmogenic sports. We suggest that further investigations should be focused on factors influencing gender difference of the prevalence of EIB. We recommend to include an EIB screening in preparticipation examination.

\section{Acknowledgements}

We thanks all students, teachers and coaches of ragunan Sport School for good cooperation. We also thank dr. Soerjadi and staff of the Center of Education and Fitness, Department of National Education for their permission to use their facilities, and dr. Wahyuni RH for technical assistance.

\section{REFERENCES}

1. Milgrom H, Taussig LM. Keeping children with exerciseinduced asthma. Pediatrics. 1999; 104(3): e38 (Epub 1999 Sept 3).

2. Ross RG. The prevalence of reversible airway obstruction in professional football player. Med Sci Sports Exerc. 2000;32(12):1985-9.

3. Storms WW. Exercise-induced asthma: diagnosis and treatment for the recreational or elite athlete. Med Sci Sports Exerc. 1999;31 Suppl 1:S33-8.

4. Wilber RL, Rundell KW, Szmedra L, Jenkinson DM, Im J, Drake SD. Incidence of exercise-induced bronchospasm in Olympic winter sport athletes. Med Sci Sports Exerc. 2000;32(4):732-7.

5. Dickinson JW, Whyte GP, McConnell AK, Harries MG. Screening elite winter athletes for exercise induced asthma: a comparison of three challenge methods. $\mathrm{Br} \mathrm{J}$ Sports Med. 2006;40:179-82.

6. Halstrand TS, Curtis JR, Koepsell TD, Martin DP, Schoene RB, Sullivan SD, et al. Effectiveness of screening examinations to detect unrecognized exercise-induced bronchoconstriction. J Pediatr. 2002;141(3):343-9.

7. Holzer K, Brukner P. Screening of athletes for exercise-induced bronchoconstriction. Clin J Sport Med. 2004; 14:134-8.

8. Mannix ET, Manfredi F, Farber MO. A comparison of two challenge tests for identifying exercise-induced bronchospasm in figure skaters. Chest. 1999;115:649-53.

9. Rupp NT, Guill MF, Brudno S. Unrecognized exerciseinduced bronchospasm in adolescent athletes. Am J Dis Child. 1992;146:941-4.

10. Mandhane PJ, Greene JM, Cowan JO, Taylor RD, Sears MR. Sex differences in factors associated with childhoodand adolescent- onset wheeze. Am J Respir Crit Care Med. 2005; 172:45-54.

11. de Marco R, Locatelli F, Sunyer J, Burney P. Differences in incidence of reported asthma related to age in men and women. A retrospective analysis of the data of the European Respiratory Health Survey. Am J Respir Crit Care Med. 2000;162:68-74. 